\title{
Stereotyping of the Russian Orthodox Church in Fake News in the Context of the COVID-19 Pandemic: Semiotic and Legal Analysis
}

\author{
Yulia Erokhina ${ }^{1} \mathbb{D}$
}

Accepted: 20 January 2022 / Published online: 23 February 2022

(c) The Author(s), under exclusive licence to Springer Nature B.V. 2022

\begin{abstract}
Fake news is created as ordinary news stylistically but it consists of deliberate disinformation or hoaxes (aimed at misinforming or deceiving people). The text is generally constructed to cause negative emotions and feelings in readers: fear, panic, distrust, and paranoia. It is done to manipulate the opinion and consciousness of a large number of people and eventually leads to changes in the values, ideas and attitudes that already exist in the public awareness. The result is a schism that has already gone beyond the usual spiritual strife. Moreover, its expansion has weakened the defining feature of Russian Orthodoxy which lies in trust and support of the state and authorities. The Russian Orthodox Church has to deal not only with public health crisis but also with profound differences within its ranks over the churchgoers' behavior in the conditions of a pandemic. The article analyzes legal regulations and mechanisms for countering fake news about the Russian Orthodox Church, and provides examples from the judicial practice. It also determines the mechanisms of the worshippers' reaction to the fake news involving the Russian Orthodox Church. Using semiotic methodology, the author reveals re-encoding of the symbolic meaning of such signs as "Russian Orthodox cross" and "red cross". The connotative meaning of these signs leads to contradictions in the conditions of the COVID-19 pandemic.
\end{abstract}

Keywords Fake news · Semiotics · Entropy · Negentropy · Pandemic $\cdot$ Church · Stereotypization

"My friend, the real truth is always implausible, did you know that? To make the truth more plausible, it's absolutely necessary to mix a bit of falsehood with it. People have always done so."

Yulia Erokhina

yulia-erohina@yandex.ru; yerohina@hse.ru

1 School for Theory of Law and Cross-sectoral Legal Disciplines, Faculty of Law, HSE

University, Moscow, Russian Federation 


\section{Introduction}

The fake news phenomenon is a part of a new reality, the way the pandemic caused by the SARS-CoV-2 coronavirus is. Fake news, the central term of the post-truth era, is most often defined as false or misleading information presented in a form of news. Complex ideological changes are taking place in society since the pandemic has caused a serious surge of aggression, hatred and xenophobia. Adherents of various religions from all over the world are more opposed to restrictions regarding mass gatherings than non-believers as they see it as an encroachment on their religious freedom. However, in Russia, the clash between religious faith and public health turned out to be especially acute and hostile, since the memories of the persecution of faith in the 20th century have made priests and their flock very sensitive to any restrictions of religious rituals.

The Constitution of the Russian Federation has recently been amended with the alterations approved during the all-Russia vote on July 1, 2020. Thus, Paragraph 2 of Article 67.1 stipulates that "the Russian Federation, united by a thousand-year history, preserves the memory of the ancestors who gave us ideals and faith in God, as well as continuity in the development of the Russian state, and recognizes the historically established state unity." So, faith in God is one of the important criteria for the self-identification of Russian people; part of the cultural code. That is why the erosion of traditional Russian spiritual and moral values through external pseudocultural and informational expansion as well as through fake news about the Russian Orthodox Church is treated as a threat to national security in terms of culture.

The Russian-speaking segment of the Internet is filled with news about some cynical or simply absurd actions and statements of the Russian Orthodox Church and its representatives about COVID-19. Such false news is spreading with great speed; comments and statements of the Internet users in this regard are also growing exponentially, and this causes emotional tension in society. Since the article examines a rapidly changing and developing current reality, it is based on qualitative research of both scientific data and most up-to-date and reliable open-source information including the Internet and fake news resources.

Addressing fake news requires a multidisciplinary effort [64]. Moreover, it is important to determine the methodology and strategy of the research. Certain attempts have been made recently to systematize methods and techniques for fake news detection and further prospects in this area have been shaped in the works of Zhou X. and Zafrani R. [74]; Collins, B., Hoang, D.T., Nguyen, N.T., Hwang, D. [12]; Shabani, S., Sokhn, M. [59]; Olszowski R. [47] et al.

In "A Survey of Fake News: Fundamental Theories, Detection Methods, and Opportunities" the authors subdivide the methods of combating fake news into four categories: knowledge-based (manual and automatic fact checking); style-based (analysis of the text at the level of lexicon, syntax, mood and rhetorical relations); distribution-based (the analysis of fake news distribution, i.e., how users distribute it), and source-based analysis (the assessment of fake news source reliability). 
Based on the above-mentioned classification, this study adopts the following methods:

- knowledge-based analysis (manual fact-checking has been performed),

- source-based analysis (the assessment of the reliability of the news source has been carried out).

Manual verification is used in this research to assess information reliability by comparing the knowledge extracted from the analyzed information content (for example, statements or announcements) with the known facts. Thus, it is determined where the information comes from and the news source status, then it is checked whether the information that regularly comes from this source has previously been confirmed and whether it is supported by links to other sources; after that the primary source of information and the date of the news are determined; then the information is further evaluated on the basis of how different it is from the comments, the emotionality of the information content and other aspects are also analyzed.

It should be noted that quantitative and automated verification of fake information methods have some drawbacks in view of the fact that the content of fake news tends to develop and change quickly, and therefore the methods that are effective for detecting disinformation today may not be equally effective tomorrow. It can be illustrated by a situation with the growth of fake news about COVID-19 in 2020 when the classifiers trained to deal mainly with political content were probably ineffective to detect new false and misleading statements concerning health [20: p. 395].

It should be recognized that it is quite difficult to identify fake news authors. According to K. Gradon, national states seeking to complicate the situation abroad, as well as rogue governments focused on a deliberate disruption of the life of foreign population can be among them. Presumably, any group or organization that intends to be economically or politically profitable, whether it is a terrorist organization, an extremist or organized crime group, can be engaged in fake news production. At the same time and as it is often the case in the online environment, a group of non-state actors who conduct the so-called trolling campaigns with the aim of spreading chaos and confusion may also be involved in digital disinformation campaigns [22: p. 136].

However, it seems premature to give a detailed analysis of the subjects of misinformation related to the COVID-19 pandemic and the Russian Orthodox Church, since the situation is developing rapidly and new forms and directions of fake news production appear every day. The goals of a disinformation campaign can be broad, for example, to sow discord in the population, or targeted, for example, to promote a counter-narrative to internal protests. Furthermore, all types of information are employed including fake information, false denunciation, disinformation, misinformation, propaganda and authentic information.

This particular study deals with fake information or a message with a reduced or missing value for society that presents itself as a valuable one. At the same time, we believe that fake information should be treated as social information, since it significantly affects public opinion. Fake news is generally aimed either at public safety, or the safety of a particular person or social group. Thus, by creating and distributing fake information, an indeterminate subject seeks to introduce unprecedented chaos, 
fear and uncertainty, which deliberately increases social entropy (the term "entropy" is used in various fields of science as a measure of disorder and randomness [3, 16, $18,23,25,28,31,34,48,54,55,56,57,58,61,75,76])$. This creates grounds for the destabilization of the situation in the country, the disunity of the nation and the destruction of the foundations of Russian Orthodoxy.

Postulating law as a specific form of mediation of various material and ideological relations developing in society, it should also be posited that law, being "embedded" in various levels of social existence, changes along with it and passes into a new qualitative state. Depending on the combination of internal and external factors, a society can function effectively in a stationary mode at a certain level of entropy (the term "entropy" is practically never used in legal science $[13,14])$, though in the case of its uncontrolled growth, there is always a possibility of a structural or systemic crisis, while in the case of an increase in negentropy (negative entropy) a society may even degrade as a system. There are different ways to influence the factors that determine the course of entropic processes in society.

\section{Fake News about the Russian Orthodox Church in the Context of the COVID-19 Pandemic as Factors of Social Entropy}

In order to analyze fake news as factors of social entropy that affect its increase, optimum or decline, it seems reasonable to map out and solve the following research tasks:

- to come up with the definition of the general concept of "entropy factor" and identify the factors that somehow influence social entropy;

- to classify and rank the entropy factors so that to enhance the concept of "entropy factor" with a particular meaning.

Factors create real conditions for social entropy to originate, exist and change. The factor approach is widely used in various branches of knowledge to address diverse problems $[6,16,19,21,26,32,33,35,43,44,50,53,69]$. Factor analysis provides a non-trivial solution, since it is quite difficult to predict the latter both qualitatively and quantitatively. The established practice of studying entropy in relation to physical and social systems is based on the fact that entropy is a characteristic of open and self-organizing systems. In the context of a pandemic, fake news should be considered among external factors that affect the entropy optimum of society. Since the Russian Orthodox Church is a fundamental pillar of spiritual and moral values and the history of Russian culture in the modern Russian society, fake news about it acquires a special resonance [30]. Therefore, the research focuses on the fake news segment on the Internet where the Russian language content dominates. For the sake of the research, it seems appropriate to subdivide fake news about the Russian Orthodox Church into several blocks.

Block 1 Religious faith is used to create fake faith, or the so-called "fake Orthodoxy" in the process of generating fake news about the Russian Orthodox Church (Fig. 1). 
Fig. 1 Fan $(k) e$, painted by Yulia Erokhina

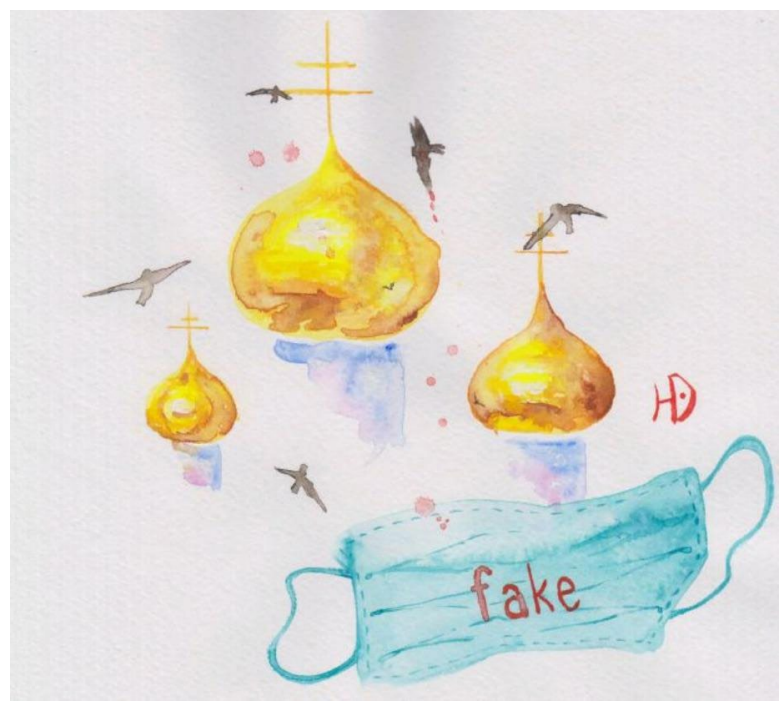

The weak point of the Orthodox mass media internet audience consists in the fact that they are kind and trusting people, who are as a rule willing to help. Many of them trust Internet sources the same way they trust radio or newspaper ones. In this regard, the main impact triggers are: paranoia and distrust (the feeling that someone or something is dangerous and we are not informed about it is familiar to everyone); fear and panic (when a person is excited, s/he does not think, but acts - likes, reposts and shares the content in social networks and chats); empathy (news presents everything in such a way as to cause sympathy).

An important point that $\mathrm{K}$. Shevtsov draws our attention to is the identity that we assign to ourselves in the digital universe, while "extending full trust in everything that corresponds to the accepted identity and is able to expand its recognition and implementation in the world." [62]. For example, having accepted the identity of an Orthodox Christian, a person is faced with the fact that from now on any remarks about Orthodoxy bring joy or suffering, offer delight or cause rage. Undoubtedly, this kind of sensation allows us to navigate the flows of information and events, serving as the basis for our own actions, which strengthen this feeling even more by either allowing us to increase the degree of pleasure from feeling "so-and-so", or reducing the degree of displeasure. Such actions are aimed at manipulating the opinion and consciousness of a large number of people and lead to a change in the values, ideas and attitudes already existing in the public consciousness.

The above stated information becomes more comprehensible when compared with the "knowledge-ignorance" dichotomy. According to C. Shannon [60], information reduces "ignorance", and according to $\mathrm{N}$. Wiener [70, 71, 72] and L. Floridi [18], information increases "knowledge". "Ignorance" refers to "non-factors" [45], that is, ignorance is the oppositional magnitude [66] formed by the negation of the other magnitude, namely "knowledge". A. Narinyani believes that "non-factors are by no means something outlandish; they are embedded in our picture of the world and 
serve as the main component of knowledge, being its matter and building material" [45]. Thus, fake news, treated as information, can reduce "ignorance" and increase "knowledge".

The concepts of knowledge and ignorance are related to the concepts of consistency and chaos. Entropy, which is used to determine information that removes uncertainty, characterizes disorder, disorganization and chaos; on the contrary, the concept of negentropy is introduced to characterize consistency. A meaningful message, a counterargument and a refutation of fake news are all examples of negentropy. Messages including fake news that remove uncertainty are examples of entropy. Different types of information have different qualities. There is no doubt that information that removes uncertainty has a different quality compared to information that creates knowledge. This highlights the difference between negentropy and entropy in a qualitative sense, they cannot be equated [73].

It should also be considered that various types of information require different conditions of use. Information that removes uncertainty is associated with entropy. Therefore, fake news removes uncertainty to some extent, but does not create knowledge due to the fact that this news, though stylistically designed as real news, is at least partially false. The text is constructed in such a way as to evoke negative emotions and feelings in readers: fear, panic, distrust. In order to attract attention of the target audience, the headlines of the articles in social media can be provocative, shocking, scandalous, or even panicky. Let us take for example, the headline of an Internet message: "COVID is an INSTRUMENT of the ANTICHRIST ... and his servants in the Church. They openly build up the religion of the devil." It is essential that the words used in the headline generate fake news, which is the most effective means of constructing a socially significant event, though the one of an absurd nature. If we take the individual words "church", "antichrist", "devil", we will see that they are marker words that form the target audience. A person who is far from Orthodoxy will most likely not pay attention to this heading. However, an Orthodox Christian will most probably get interested, because these words are used both in religious texts and in the speeches of clergymen, even though they have a different connotative meaning there.

In the article "On Seven Types of Fake Orthodoxy" by archpriest Andrew Phillips, an Englishman who has become an Orthodox priest, one can find an example of reduced uncertainty in a meaningful counterargument, which reflects the facts in accordance with the Orthodox doctrine: "For almost 50 years of being in the Orthodox Church, I have seen how the devil can fake absolutely everything. This is because he himself is a fake - a fake god, although many people still worship him. For he is a liar and the father of lies (John 8:44), the devil is able to falsify almost any human activity, including faith" [51].

\footnotetext{
${ }^{1}$ KOVID - INSTRUMENT ANTIKHRISTA... i ego slug v tserkvi. Oni otkryto vystraivayut religiyu d'yavola. [COVID is an INSTRUMENT of the ANTICHRIST ... and his servants in the Church. They openly build up the religion of the devil]. https://3rm.info/main/82474-kovid-instrument-antihrista-iego-slug-v-vcerkvi-oni-otkryto-vystraivajut-religiju-djavola.html. Accessed on 20th September 2021. (In Russian).
} 
Block 2 Since the end of 2020, a number of countries have started mass vaccination against COVID-19. In fake news, the focus has also shifted to vaccination. In particular, such fake headlines could be found on pseudo-religious sites: "VACCINOFASCISTS NEED TO BE STOPPED ... Pregnant Khabarovsk women are threatened that their children will be taken away because of their refusal to vaccinate" or "VERY IMPORTANT!!! Signs of the Apocalypse: Everything will not be the way we have expected! Chipization and getting the Mark of the Beast, apparently, will be carried out through... COMPULSORY VACCINATION!"’3

There is fake information that is quite difficult to identify and distinguish. Let us analyze the material by Andrew Higgins "A 'Breakdown of Trust': Pandemic Corrodes Church-State Ties in Russia" (The New York Times, USA) ${ }^{4}$. On some Internet sites, this material allegedly belongs to the authorship of other people: Oleg Matsnev and Sophia Kishkovsky ${ }^{5}$. This example might suggest that there is some implication here to the non-Russian origin of this message, which may either give the text expertise and authority, or on the contrary sow panic allegedly associated with the foreign agent influence on public life in Russia, or at least cause suspicion and uncertainty. One way or another, such fakes cause a negative anti-church wave, and affect both national and interpersonal interests.

Obviously, the Russian Orthodox Church opponents aim at millions of Russian Orthodox Christians, while attacking the Church. It is carried out through using incorrect criticism of vaccination by representatives of the Russian Orthodox Church as well as by spreading fake news about the Church hierocracy, which advocates mandatory vaccination and prohibits unvaccinated parishioners to participate in the Sacraments [67]. If we take this line of reasoning further, we will indicate the fact that fake news about vaccination and the Russian Orthodox Church broadcasts a hidden appeal to reject various kinds of nationwide campaigns initiated by the state authorities, and vaccination campaigns, in particular. This leads to a schism that does not only go beyond the usual spiritual strife but also expands and weakens an impor-

\footnotetext{
2 VAKTSINOFASHISTOV NUZHNO OSTANOVIT... beremennym habarovchankam ugrozhayut otobrat dete iz-za otkaza ot vaktsinatsii [VACCINOFASCISTS NEED TO BE STOPPED ... Pregnant Khabarovsk women are threatened that their children will be taken away because of their refusal of vaccination]. https://3rm.info/main/86303-vakcinofashistov-nuzhno-ostanovit-beremennymhabarovchankam-ugrozhajut-otobrat-detej-iz-za-otkaza-ot-vakcinacii.html. Accessed on 20th September 2021. (In Russian).

${ }^{3}$ OCHEN' VAZHNO!!! Znameniya Apokalipsisa: Vse budet ne tak, kak my predpolagali! Chipizatsiya i naneseniye "metki Zverya", po vsey vidimosti, budet osushchestvlyat'sya cherez... PRINUDITEL'NOE VAKTSINIROVANIE! [VERY IMPORTANT!!! Signs of the Apocalypse: Everything will not be the way we have expected! Chipization and getting the Mark of the Beast, apparently, will be carried out through... COMPULSORY VACCINATION!]. https://monomah.org/archivies/22397. Accessed on 20th September 2021. (In Russian).

${ }^{4}$ Higgins Andrew. Utrata doveriya: pandemiya razrushaet svyazi mezhdu tserkov'yu i rossiiskim gosudarstvom [A 'Breakdown of Trust': Pandemic Corrodes Church-State Ties in Russia]. (The New York Times, CША). https://inosmi.ru/social/20200506/247376645.html. Accessed on 20th September 2021. (In Russian).

${ }^{5}$ According to Rambler, the material for the article is given by Oleg Matsnev and Sophia Kishkovsky. https://news.rambler.ru/other/44135595/?utm_content=news_media\&utm_medium=read_more\&utm_ source $=$ copylink. Accessed on 20th September 2021. (In Russian).
} 
tant feature of Russian Orthodoxy which lies in trust in the state and support of the authorities.

Having analyzed the two blocks of fake news about the Russian Orthodox Church, it is worth noting that in the most general form, entropy factors are real states of phenomenon considered in the totality of their static and dynamic properties, in accordance with their role in the behavior of systems and the entropy change in them. It should be emphasized that in relation to social entropy, the concept of "factor" retains its ambiguity. Therefore, it cannot be identified only with one particular meaning, for example, social causes [65: p. 32], etc. Thus, the phenomenon understood by the entropy factor can be a cause, a concomitant circumstance, a prerequisite, a condition, an occasion, etc.; its meaning in each case depends on the context. It is equally important to mention that the concept of "entropy factor" is extremely abstract and should be considered as a generic one. So, in each particular case, an entropy factor is understood as a specific circumstance that affects a specific phenomenon or process.

If fake news can be considered as external factors of social entropy, then the actions of the Russian Orthodox Church should be treated as its internal factors. Despite the fact that in 2020, the Russian Orthodox Church introduced a number of measures to counteract the threat of coronavirus infection of the population, the Church faced a deep disagreement in its own ranks about what to do for believers in the conditions of the COVID-19 pandemic.

Therefore, in this part we have highlighted factors which affect social entropy, namely fake news as external factors and actions of individual representatives of the Russian Orthodox Church, causing chaos and uncertainty, and having a strong resonance in society as internal factors.

\section{Stereotyping of the Russian Orthodox Church in Fake News as a Propaganda Method}

"The more there is advertising, slogans, dogmas, and ignorance, the less depth in thinking, authentic freedom, and reasonableness is there. Egotism, corruption, crime, inflation, stimulation of destructive activity and inhibition of constructive work, inadequate distribution of public energy - all this encourages entropy processes in society," writes N. Kajtez [31: p. 85].

Fake news covering Russian Orthodox Church, COVID and vaccination (external factors), as well as destructive actions of individual representatives of the Russian Orthodox Church, namely the denial of the threat of the pandemic and boycotting anti-epidemic measures (internal factors), lead to social entropy increase. Consequently, this destabilizes the situation in society by stereotyping the negative perception of the Russian Orthodox Church activity and negatively affecting its image. Historically, a stereotype is formed due to the fact that different groups of people such as nations, classes, or professional groups have certain characteristics or traditions. Stereotypes in this sense are sometimes formed over centuries and become the basis for a tradition that defies empirical and rational verification. In addition, stereotypes perform a number of functions in the process of interpersonal interaction: they explain and justify existing social relations; protect group values; provide cogni- 
tive intergroup differentiation; express, preserve and transfer cultural and historical experience; ensure the economy of thinking [29].

However, many new stereotypes formed in the short term of the COVID-19 pandemic, have revealed real conflicts within the church structure as well as between the church, society and the state. Stereotypes can be viewed as false and devoid of logic imperfect actions or biased judgments. Consequently, the discussion is doomed to collapse among the people who represent an atheistic system of views, because they treat a believer, in this case an Orthodox Christian, as a typical set of behavioral patterns and cliches that they are to challenge. Thus, instead of talking to a specific person, they will fight the system of views they deeply reject.

It seems reasonable now to go into detail and describe those frequent schemes of the stereotyping process that prevent us from seeing an interlocutor as an individual. These stereotyping ideas include the perception of an Orthodox follower as a narrowminded person with whom there is nothing to talk about; treatment of a believer as an absolutely illogical person; confidence that Orthodox worshippers are fanatics and masochists prone to neurosis; assurance that Orthodox Christians have fallen behind life [24].

These stereotypes are being formed under the influence of external factors of entropy growth, namely fake news. This can be illustrated with the following examples of fake messages:

"Human cell lines originating from an embryo are used to produce Covid-19 vaccines. A representative of the Church of Greece says that he will not be vaccinated. Those who are worried about being infected while taking Holy Communion should feel much more anxious at the thought of the desecration of our body, which may occur when this material, obtained from murdered unbaptized infants, gets there. It is the product of murder. It is a terrible remedy." 6

"The mass use of a Covid-19 vaccine, which was created within a few months, is a diabolical experiment on humanity with disastrous consequences, and it is the reason the vaccine has been developed for."7

"The most commonly used barcodes are one-dimensional or linear and twodimensional or QR codes. No matter whether a barcode is one-dimensional or twodimensional, it contains the Apocalyptic number 666." 8

These messages are aimed at causing a psychological reaction to them, which in this case is automatic. According to an American researcher R. O'Hara, the intensity of this reaction is proportional to the strength of the emotional impact. Stereotypes as well as fake news can be easily spread and even imposed on people via the Internet. Fake news is a trigger for generating negative stereotypes about the Russian Orthodox Church. The formation of a stereotype undergoes three stages: leveling, sharpening and assimilation [46]. In this light, the accuracy of information transmission loses

\footnotetext{
${ }^{6}$ https://vk.com/wall129912296_104756. Accessed on 20th September 2021. (In Russian).

${ }^{7}$ SGORYAT IZNUTRI... PRINYAVSHIE VAKTSINU OT KOVIDA [Those who have been vaccinated will burn out from the inside]. https://pravdoiskanie.livejournal.com/5152665.html. Accessed on 20th September 2021. (In Russian).

${ }^{8}$ SGORYAT IZNUTRI... PRINYAVSHIE VAKTSINU OT KOVIDA [Those who have been vacinated will burn out from the inside]. https://pravdoiskanie.livejournal.com/5152665.html. Accessed on 20th September 2021. (In Russian).
} 
its value, and emotions come to the fore. In other words, the active development of the Internet has led humanity into the era of post-truth with real facts being of less value than psychological reactions to them.

Many stereotypes about the Russian Orthodox Church are inherently false, erroneous and lead to negative consequences. The Russian Orthodox Church has been and still remains one of the targets for fake news in order to form negative stereotypes, though the mechanism of increasing attendance requires hatred not specifically for the Russian Orthodox Church, but hatred in general. In this sense, ethnic hate would fit well, but this might result in having problems with the law, whereas the Russian Orthodox Church is a relatively safe target for attacks.

Stereotypes are acquired as skills, norms or values with the social role played by an individual being of particular importance. People do not study stereotypes in the context of reflexive thinking, they simply assimilate and approve of them. Bounded rationality, emotionality, instinctiveness, and lack of reflexivity - all these properties of consciousness or, in a broader sense, human behavior - increase the susceptibility to the assimilation of stereotypes and reduce the chances of destereotypization [36]. Based on general psychological mechanisms, stereotypization is a complex socio-psychological phenomenon that performs such functions as: maintaining the identification of a person, group or phenomenon; justifying or explaining their possible negative or positive attitudes, etc. Social immunity includes common sense and personal experience of each member of society. After all, you can publish any fake news on the Internet, but you cannot force people to spread them.

When researching the process of stereotyping the Russian Orthodox Church in fake news in the context of the COVID-19 pandemic, it makes sense to consider measures to reduce social entropy and increase negentropy, and their significance. The following pattern has been revealed: when we try to fight unreliable information, we only root it deeper in mass consciousness $[37,68]$. That is, a powerful counteraction

Fig. 2 Inj(f)ection, painted by Yulia Erokhina

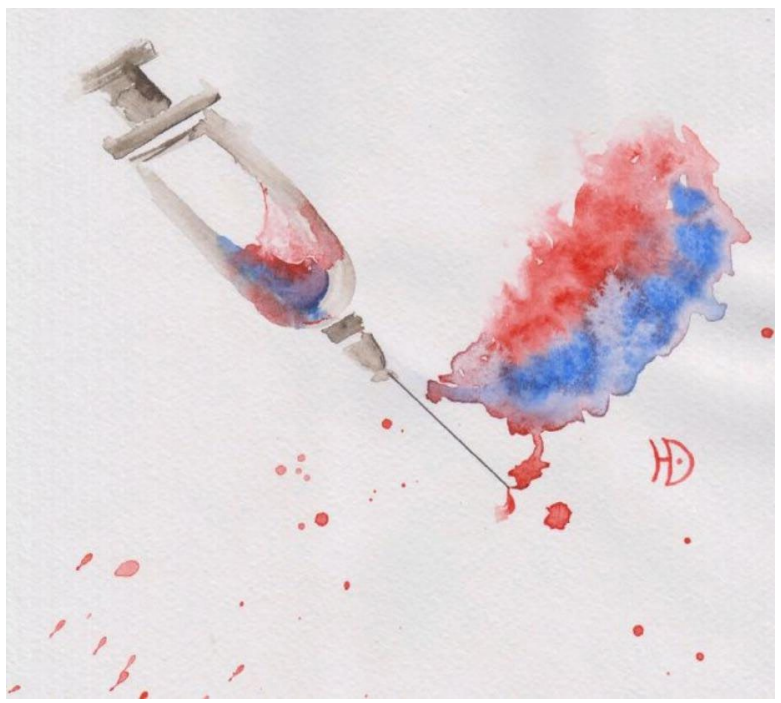


deployed in response to fake news publishing will also be ineffective. In fact, measures aimed at ordering and stabilizing the situation in society do not work as they do not lead to the decrease in social entropy. Moreover, refutation is considered to be a more complex communication tool than accusation, since in an attempt to refute inaccurate information, it is, in fact, distributed to a wider circle of people. Besides, having been acquired the information occupies a large place in memory, and it usually takes much more effort to refute it [52].

The promotion of the vaccination against coronavirus infection by clergy may be viewed as measures to reduce social entropy and streamline public relations (Fig. 2).

The history of the Russian Orthodox Church knows examples of the active participation of clergy in the dissemination of vaccination behavior with the aim of preserving people's lives and health by this medical procedure. In particular, the decree of the Holy Governing Synod of 1804 recommended that bishops and priests should explain the benefits of vaccination against smallpox to people. Besides, clergy had to study the basics of vaccination against this disease as part of their general education at that time. St. Innocent of Moscow also supported the spread of vaccination programmes [4: p. 82-83].

In May, 2021 the round table "Vaccination: Ethical Problems in the Light of Orthodox Doctrine" was held at the Sretensky Theological Academy. At the conclusion of the event the participants issued a final document which stated it impermissible and sinful to spread false evidence identifying the vaccine as "the seal of the Antichrist" as well as conspiracy theories on the alleged use of vaccines as a secret means of introducing micro-chips into the human race .

Thus, propaganda by means of fake news is not aimed at a human mind, but at human emotions. The main method of propaganda is stereotypization, i.e., the development of stereotypical ideas about the Russian Orthodox Church with the help of inaccurate information. Fake news acts as a trigger for the formation of negative stereotypes, entailing an increase in social entropy and destabilizing public relations in the Russian Federation. Stereotypical thoughts, judgments, assessments and images are accumulated in ready-made formulas, and manifest themselves in labels and false generalizations. Accordingly, legal regulation of public relations may presumably result in reducing the growth of social entropy and achieving entropy optimum. Law, being a powerful ideological force, acts as a stimulator in the formation and development of behavioral motives in no different way than other means of ideological influence.

\section{Legal Regulation qua Means of Entropy Optimum Attainment}

Entropy optimum is a theoretical model, which reflects a system's behavior with regard to the variations in the entropy value fluctuating from the minimal value possible (critical negative entropy) to its maximum (critical entropic value).

\footnotetext{
9 The final document of the round table "Vaccination: Ethical problems in the Light of Orthodox Doctrine" http://www.patriarchia.ru/db/text/5811676.html. Accessed on 20th September 2021. (In Russian).
} 
When there is an abundance of fake news during the pandemic in the conditions of emergent new social relations, aggravated by the negative consequences of isolation and fear, there is an urgent need for a prompt reaction on the part of the state in respect of the situation stabilization and the reduction of social entropy. This reaction most commonly finds manifestation via legal regulation. COVID-19 pandemic has posed significant challenges in the sphere of legislation, since it was and is necessary to quickly adapt legal mechanisms to the new reality emerging.

Let us delineate the major statutes of the Russian legislation as regards the issue in question that are considered as imperatives and that are realized by means of restrictive and prohibitory legal regulation. The detection of fake news has been carried out on the basis of Article 15.3, Part 1 of the Law "Regarding information, information technologies and information protection." 10

In 2019 and 2020, alterations were introduced into the administrative and criminal legislation of the Russian Federation that prescribed legal liability for the distribution of fake news.

Administrative penalty for the spreading of false information (Article 13.15, Parts 9, 10, 11 of the Administrative Offences Code of the Russian Federation) presupposes fines up to 100,000 rubles $^{11}$ with the possibility of further confiscation of the object of legal violation. In case of the repeated offence, the sum of the fine is to be extended to 300,000 rubles. For civil servants, government officials and legal entities the fines are meant to be even higher.

In case fake news causes death or bodily harm or damage to property, mass disturbances and breach of the social order or security, breakdown and inactivation of the objects of critical infrastructure, including transport, social and other, fines to up to $10,000,000$ rubles are stipulated in the legislation (for legal entities).

The Prosecutor's Office of the Russian Federation is notified of all the cases of initiation of administrative cases, which are specified in Parts 9 to 11 of Article 13.15 of the Administrative Offenses Code, within $24 \mathrm{~h}$ since they are committed.

For citizens, the most grave and serious sentence for the distribution of fake news is covered by Article 207.1 of the Criminal Code of the Russian Federation (which covers the cases of the public distribution of deliberately false and fraudulent information regarding the events and factors posing threat to life and safety of the general public) and Article 207.2 (public distribution of the deliberately false, socially significant information, that has led to grave consequences).

In case the circulation of fake news has resulted in the bodily harm and injury through negligence, the guilty party is to be imprisoned for a period up to three years, in case of death or serious injury or mutilation - sentenced to up to five years of incarceration.

Having said that, though, it bears noting that the very fact of the distribution of false information that is socially significant does not necessarily constitute a felony in

\footnotetext{
10 The Federal Law 149 -Ф3 "Regarding information, information technologies and information protection" adopted on July 27, 2006. https://base.garant.ru/12148555/. Accessed on 20th September 2021. (In Russian).

11 The currency exchange rate (at the rate of the Russian Federation Central Bank), as of October 19, 2021, constituted 82.4592 rubles (RUB) for 1 euro.
} 
itself, nor amount to a crime. Deliberately false information (as stipulated in Articles 207.1 and 207.2 of the Criminal Code of the Russian Federation) is defined as information (that is, news, data, evidence, etc.) a priori not corresponding to reality, and the person spreading the misinformation happens to be aware of the fact all along. One of the prerequisites of the incurrence of liability as postulated in Articles 207.1 or 207.2 of the Criminal Code of the Russian Federation is distribution of the deliberately false information disguised as true. The distribution of the deliberately false information ought to be considered public when this information is addressed at the group of people or the general public at large and when it is expressed in any fashion available and accessible to them. The public nature of the distribution of deliberately false information may manifest in the employment for this purpose of certain media: mass media, social and telecommunications networks, including messengers, such as WhatsApp, Viber, Telegram, etc., or via email spamming, or, possibly, during public speeches or via posters or fliers and handouts, etc. When it comes to officials and public authorities, there are special provisions outlined in Article 285 (Abuse of Power) and Article 286 (Official Misconduct) of the Criminal Code of the Russian Federation. Article 236 (Violation of Sanitary and Hygiene Standards) of the Criminal Code of the Russian Federation has been redrafted and amended. Depending on the qualifying attributes and consequences, the sentence for the violation of sanitary and hygiene regulations may vary from a fine of 500,000 rubles to imprisonment for the term to up to seven years.

The prohibitions directed at the legal persons that are stipulated in the Administrative Offences Code and the Criminal Code of the Russian Federation serve as an indispensable means of the protection of law in the conditions of the COVID-19 pandemic and the sustaining of the entropy optimum in the society. Simultaneously, one cannot ignore the problematic aspects arising in the context of realization of the right to freedom of faith and conscience in Russia. International statutes and the legislation of the Russian Federation guarantee freedom of faith, including the right to worship and practice any religion, hold services and participate in other religious rituals.

This right may be restricted, however, for the sake of the protection of health of citizens only by the Federal Law (Part 3, Article 55 of the Constitution of the Russian Federation) and may not be restricted in the conditions of force majeure and state of emergency (Part 3, Article 56 of the Constitution of the Russian Federation). Additionally, as per legal acts regarding freedom of worship, religious institutions are entitled to holding religious sermons and rites, ceremonies and sacraments without obstruction (i.e., without any restrictions or limitations imposed by the state and authorities), to perform religious rituals and worship in the religious buildings in the manner prescribed by the internal regulations of the religious institutions. Unlawful obstruction of the activity of religious organizations or administration of sermons and other religious ceremonies is subject to criminal liability.

The report of the Presidential Council of the Russian Federation on the Development of the Civil Society and Human Rights on the subject of the lessons the pandemic teaches in terms of respect for and observance of human rights and fundamental freedoms of citizens describes numerous cases of restrictions as regards the functioning of religious institutions, initiated by the bodies of state power of 
the subjects (territorial entities) of the Russian Federation. ${ }^{12}$ Let us delineate several such cases: by the directive \# 161 of the Governor of Saint-Petersburg, dated March 26,2020 , the attendance of religious buildings was prohibited; the letter of the ViceGovernor of Ryazan Oblast \# 2-29/837, dated April 8, 2020, addressed to the Diocese of the Russian Orthodox Church contained the imperative to close down all the churches and places of worship for parishioners under the penalty of administrative liability; the Governor of the Amur Oblast decreed (regulation \# 41-r dated March $27,2020)$ that the activity of all religious institutions and places of worship be suspended, alongside the functioning of all buildings and objects intended for praying, worship, pilgrimages and so on. In other territories of the Russian Federation, for example, in Kemerov Oblast, the heads of municipal districts and boroughs received telephone messages and dispatches from governors or their deputies requesting the inspection of the orthodox churches regarding the presence or absence of parishioners during sermons.

Let us proceed by analyzing practices of administration of legal and normative acts undertaken with the view to counter and manage the spreading of the novel coronavirus infection; concurrently, we will consider the issues mostly regarding the problem of fake news distribution covering the Russian Orthodox Church. Let us consider two cases, which were in the limelight and caused significant hype and public attention, one of them criminal, with the accused being a journalist, and the other administrative, the accused being a member of the clergy.

\subsection{A Criminal Case}

On April 16, 2020, in Nizhny Novgorod, the first criminal case was initiated against a reporter accused of spreading fake news regarding the novel coronavirus infection, pursuant to Article 207.1 of the Criminal Code of the Russian Federation. The defendant of the criminal case in question was an editor of the internet project and the author of the corresponding Telegram messenger A. Pichugin.

The criminal case was initiated after a publication was released on April 12, 2020 on the specified Telegram channel that rendered the story replete with fabrications regarding premeditated actions involving infecting the parishioners by a dangerous disease through multiple violations of epidemic control measures and norms during services held on Palm Sunday, specifically, during the service at Diveyevsky Monastery, where a great number of faithful churchgoers gathered despite the imminent threat of COVID-19. The Internet sources posted that the reason for the criminal hearing undertaken against the perpetrator, the journalist A. Pichugin, was "the sarcastic allegory, interpreted as a fake." 13

Let us consider the official documents of the legal proceedings in question.

\footnotetext{
12 The report of the Presidential Council of the Russian Federation on the Development of the Civil Society and Human Rights on the subject of observance of human rights and fundamental freedoms of citizens in the time of the pandemic and the lessons it has taught. https://www.consultant.ru/law/hotdogs/63512. html. Accessed on 20th September 2021. (In Russian).

13 The said sarcasm resulted in the criminal charges for the distribution of fake news. https://rossaprimavera.ru/news/c2492d0b. Accessed on 20th September 2021. (In Russian).
} 
An important role during such cases, that is, during investigations of fake news spreading, is played by forensic linguistic analysis. The subject of the latter is evidence (facts and circumstances), which appear significant for the criminal or administrative case in question. "Linguistic forensic analysis is a special kind of linguistic examination carried out for the purpose of identifying circumstances subject to verification within the framework of an arbitration hearing, civil lawsuit or criminal trial" [5]. The object of linguistic forensic analysis is speech (be it a single word or a complete text or several texts), presented in written form (including oral texts reproduced via letters). The product of speech may be estimated from the perspective of the aim of its formation, the meaning it contains, means of its expression and the nature of its impact on the target audience or recipient.

In accordance with the expert assessment and testimony, in the post under analysis by A. Pichugin, there are both utterances, which present information as factual statements and those which appear suppositional and conjectural. Apart from that, there is information presented qua opinion and value judgement. Experts in the field of linguistics have concluded that the information regarding real actions of a specific organization with respect to deliberate contagion of citizens was presented in the analyzed message posted by the defendant in the form of factual information, not as an opinion, supposition or subjective evaluation of certain events. The court found the defendant guilty as charged in accordance with Article 207.1 of the Criminal Code of the Russian Federation - "public distribution of deliberately false information regarding circumstances and events posing threat to safety and life of citizens under the guise of factual and authentic data." When assessing the actions of the defendant as unlawful and prohibited by the criminal law, the court took into account that the offender was spreading the information, which contributed to the formation of consistent opinions about the occurrence of real circumstances posing threat to life and safety of people, while in reality such circumstances were non-existent. At that, not only the information itself matters; the modus of expression does too, as well as linguistic means employed and paralinguistic aspects of the utterance.

\subsection{An Administrative Case}

The hearing of the administrative case (in accordance with the guidelines specified in Article 20.3.1 of the Administrative Code of the Russian Federation) against N. Romanov was held in the city court of Sverdlovsky Oblast in 2020. It was determined that on April 25, 2020, on the grounds of Sredneuralsk Convent, N. Romanov was openly and publicly voicing slogans and opinions aimed at incitement of enmity and hatred, filled with disparaging remarks meant to humiliate on account of ethnic descent, specifically those of Jewish origin, or members of social groups, persons convinced that the COVID pandemic was real, who were exercising self-isolation and appealing to others to abstain from going to church during those precarious times. The defendant called for evicting those believing in the pandemic to other regions and appealed to law enforcement agencies to free Russia from the curse and yoke of Judaism. The judges came back with the verdict that in order to prevent further offenses of a similar nature and with a view of the social danger of the offence committed and the 
age of the perpetrator, the adequate punishment for the aforementioned crime was an administrative fine. The resolution was rendered on July 23, 2020.

Taking into account the fact that in Russia Church is separated from the state, it appears worthwhile to consider the reaction of the Russian Orthodox Church to the actions of the defendant, N. Romanov (Schemonk Sergius), that amounted to his ex-communication. His Holiness the Patriarch of Moscow and All Russia Kirill ratified the resolution of the Ecclesiastical Court of Ekaterinburg Diocese as regards the excommunication of the former monk. It was chronicled that Schemonk Sergius openly and unabashedly violated the rules of conduct, which forbade him to administer the divine service, officiate public sermons, wear a pectoral cross, and leave the premises of the Monastery of John the Apostle without the written consent of the presiding bishop. The Ecclesiastical Court established the cases of slander, libel and fabrication in the official speeches of Sergius. The Court also deemed as violations of canonical norms the cessation of the commemoration of His Holiness Patriarch of Moscow and All Russia and the presiding bishop during the sermons held by Schemonk Sergius. The concluding part of the verdict maintained that through his actions, Sergius violated the oath he had taken on December 24, $2001 .^{14}$

Counter-strategies for fake information spreading via legal measures, such as prohibition, appear not valid, all things considered. Firstly, this is a long and winding path, a time-consuming and laborious process, requiring the joint efforts of a great number of professionals, experts in various fields. The counter-measures, however, ought to be prompt and swift, "here and now", as it were. Otherwise, fake news will gradually pass into the category of "unverified information" and, with time, will start to be perceived as truth. The refutation of such news, if undertaken after a long period of time, will only aggravate the situation by reminding everybody of the very fact of its circulating. Secondly, only partial measures will be accomplished - that is, the punishment of the perpetrator, who has published the notorious fake. The major objective though - the countering of fake information - will have failed to be attained.

The system of legal regulation consists of several subsystems: legislature; that of direct realization of subjective rights and legal duties; and the subsystem of the administration of law. The attainment of entropy optimum via legal regulation largely depends on the factors defining the increase or decrease of social entropy, which were analyzed prior. First and foremost, the most essential condition vouchsafing the achievement of positive results in the process of realization of rights is the parity of normative and law enforcement targets and guidelines. The aims of individual people and their alliances can hardly be identical in the first place - even when encapsulated in law. They always differ from their legal models one way or another, and this happens to be one of the most common factors and reasons for unlawful behavior. Legal regulation can be an effective means of sustaining the entropy optimum in case it is harmoniously combined with social and cultural conditions, which affect the relations regulated by law and which interact themselves.

\footnotetext{
14 "His Holiness Patriarch Kirill endorsed the decision to excommunicate Schemonk Sergius (Romanov)." http://www.patriarchia.ru/db/text/5707573.html. Accessed on 20th September 2021. (In Russian).
} 


\section{The Clash of the Connotative Meanings of the Russian Orthodox Cross and the Red Cross Symbols}

The so-called "pandemic" discourse is characterized by such connotative signifiers as negative evaluation and emotional intensity, globalization of perception, uncontrollability and unpredictability [63]. It appears that within the specified discourse it makes sense to analyze the connotative meaning of the cross as a symbol by resorting to semiotic methodology. This will allow to explicate the concept in question.

All spiritual life and activity of a person, be it language, science, mythology, religion, or art, are symbolic forms via which a person cognizes the world and organizes and structures the chaos around them, thus reducing the level of entropy.

Ernst Cassirer claims that a symbol - owing to its merging and employing two principles, that of universality and variability - has a universal significance; through symbol, Spirit is being structured and arranged in its various manifestations. Cassirer's symbolic approach towards various cultural phenomena proves to be the most productive for the study of the Cross [7-10], specifically in the context of the present research.

In Russia, in the Russian philosophical tradition, the symbol has been the focus of attention in the works of various scholars, among those Aleksei Losev [38, 39], Pavel Florensky [17], Juri Lotman [40], Merab Mamardashvili [41, 42] and others.

It is worth mentioning that non-verbal impact mechanisms of the Cross as a symbol on human behavior are beyond the methods that have been developed for textual analysis and interpretation. There is a hypothesis that the use of the semiotic method, through the iconic sign, will help define the connotative meaning of a nonverbal symbol of the cross, which is considered to be a carrier of social symbolism in Russia.

In pre-Christian cultures, the cross functioned as the symbol of the Sun and fire, as well as life itself, thus it was used as a talisman, meant to protect against evil, and a symbol of salvation.

In Christianity, the concept of the Cross finds its fullest manifestation; the Cross becomes the symbol of the one true God of Christianity. The Cross is identified with Jesus Christ, his death on the cross and his resurrection (immortalization).

The Christian Cross undergoes numerous transformations in religious and secular cultural milieus while remaining a unified and inexhaustible symbol. The advancement of Christian culture, both religious and secular, is related to the symbol of the Cross, which has found reflection in Art: architecture, Fine Arts, literature, heraldry and so on.

The primary symbolic meaning of the six-pointed Russian Orthodox cross is quite amply explicated in the liturgical text of the Nones - *Ninth Hour of the Service of the Lord's Cross*:

In the midst of two thieves, Thy Cross was found to be a balance of justice; for the one was borne down to Hades by the weight of his blasphemy; the other was raised up from his sins by the knowledge of theology.

In other words, the Cross serves as a measure, scales of sorts, indicating our inner state, as it did for the thieves on Golgotha, at the Calvary Cross. For one thief, who 
was being led to Hell because of his sin of blasphemy, his denigration of Christ, the cross turned into a crossbar of the scales, which goes all the way down, deep down because of that awful burden; another thief was released through his repentance and the words of the Lord Savior: "Verily I say unto thee, to day shalt thou be with me in Paradise" (Luke 23:43), for the Cross ascends you to the Kingdom of Heaven [15].

During the time of the pandemic, the symbol of the Cross loses its complexity and meaningfulness inherent to it, and is often equated to a sign. Any information, including fake news, always has an iconic nature and is transmitted via signs. A code (and language as well) is a system that includes the structure of signs and the rules for its functioning. The structure, in its turn, consists of the signs themselves and relations between them.

These days, the Internet is full of fake news; some campaigns that have occurred during the pandemic in numerous regions of Russia, have been exploiting the Orthodox symbols, and are aimed at destabilizing the Russian society. Currently, the society is experiencing a surge of interest towards image creation and the aesthetic exploration of reality; this also is reflected in the increasing role of visual signs that are used to generate fake news about the Russian Orthodox Church, the pandemic and vaccination, that are circulating on the Internet.

Having said that, within the framework of this research, it is relevant to consider the secondary connotative meaning of the Russian Orthodox Cross and the red cross.

The symbol of the Russian Orthodox Cross has a complex secondary connotative meaning. Its positive symbolic meaning is manifested through salvation, hope, and protection. This meaning can be surmised from the import and cultural meaning of the most familiar devout gesture in Christianity - the sign of the cross performed in prayer.

A cross most commonly preserves its negative connotation outside the religious discourse. This is explicated through Russian idioms and proverbs, for example, if translated literally, "to put a cross upon someone or something" - which means "to ignore, forget, shun or leave behind."

In the conditions of the pandemic, there is a palpable tendency to equate a symbol and a sign. For instance, a cross - in the times when the novel coronavirus infection is still on a rampage - is often perceived as a negative, bad sign, signifying the end, death.

It should be mentioned that for people who denounce the teachings of Russian Orthodox faith altogether, the Russian Orthodox Cross happens to be a sign imbued with a negative meaning. This is also connected with the mechanisms of stereotyping of the negative image of the church. A huge bulk of fake news contains appeals - allegedly on the part of the Church - to abstain from vaccination and to ignore the real dangers of the novel coronavirus infection. Concurrently, some members of the clergy, exponents of fideism, those who urge reliance on faith rather than reason in pursuit of religious truth [49], believe that that the transmission of a virus during a sermon is simply impossible: "For the members of the congregation, administering Eucharist and taking the Holy Communion from the Cup of Life can never lead to the transmission of diseases, for the faithful at all time have known that partaking of the Holy Communion - even amid the pandemic - is, on the one hand, in essence, a practical confirmation and demonstration of the selfless and total devotion to Living God, 
and, on the other hand, it is a magnificent manifestation of Love that is stronger than any human fear, even if that fear is justified." ${ }^{15}$ Metropolitan John, the priest who uttered these words, died on November 15, 2020, as a result of complications caused by COVID-19. Archimandrite Cyril (Hovorun) dwells on the problem at hand: “... at present, the proponents of fideism have no valid theological or scientifically verifiable evidence signifying the immunity of the Eucharist in the face of the threat of the coronavirus. For the most part, all their rhetoric amounts to the pleas and appeals to believe in the invincibility provided by the church. The theological arguments are even less convincing among the Orthodox fundamentalists." [27: p. 61].

So, it appears that apart from the formation of the negative stereotypes of the Russian Orthodox faith through the hands and words of the clergy of the Church themselves (both Orthodox and other denominations), there exists a certain major vector in contemporary culture, which may be dubbed a "laboratory", wherein strategies of anti-Christian tendencies pervading contemporary mass culture are being forged which is true for both Russia and other countries.

Connotation is a secondary semantic meaning, which complements the primary semantic core constituted by the information about objective reality, with semantic overtones, among those alluding to the national character and mentality, for one. We should designate the acts of artistic reflection, which, it would appear, have affected the alteration in the connotative meaning of the cross symbol. It makes sense to mention the representative of the so-called Wiener Aktionismus (Viennese Actionism) Hermann Nitsch, whose so-called "works" were exhibited in Moscow several years ago. His "actions" and permanent exhibitions of his "The Orgies Mysteries Theatre" are, essentially, illustrations of Gospel; they resort to Christian symbolism, including the image of the Cross, the latter being an element of morbid gory orgy of Bacchus, mayhem, featuring the naked bodies of the actors thrown into mad frenzy.

More often than not, the object of the assault of this contemporary art is the most sacred and sacral Christian symbolism, and most specifically, the Cross. There are blasphemous depictions of our Lord on the Cross, alluded to via the image of the crucified frog holding a mug of beer and an egg (portrayed by Martin Kippenberger) or a series of photographs of the Cross taken through the prism of a glass with the author's urine (Andres Serrano). There was also a notorious action in front of the main building of the Federal Security Service involving the activist himself being put on fire on the Cross (Pavel Krisevich). These and similar events have prepared the mass consciousness, prompting common folk to exercise nihilism and reject the symbol of the Cross altogether. This, in its turn, has found manifestation in the acute response of some members of the Russian society and even whole social groups that resulted in the assault upon Orthodox Christians on the Internet, on social platforms, and which has gradually led to the effusive formation of the negative stereotypes of the image of the Russian Orthodox Church in public consciousness.

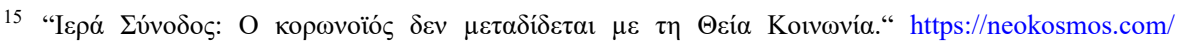
el/2020/03/10/news/iera-synodos-o-koronoios-denmetadidetai-me-ti-theia-koinonia/. ["Holy Synod: The coronavirus is not transmitted by Holy Communion"]. https://neokosmos.com/el/2020/03/10/news/ierasynodos-o-koronoios-denmetadidetai-me-ti-theia-koinonia/. Accessed on 10th August 2021.
} 
In the current circumstances, a special significance is attained by another symbolic aspect of the cross - the Red Cross. COVID-19 pandemic has become a grave challenge for Russia's healthcare system. Practically all the segments of the medical system are subject to intense pressure; this has called for a swift response and restructurization of the customary algorithms of operation.

The primary meaning behind the symbol of the Red Cross was determined by historic resolutions adopted at the international conference in 1863 that institutionalized the foundation of Wounded Soldiers Aid Society - which would later transform into Red Cross Societies and afterwards into Red Crescent Societies. Additionally, a unified distinctive emblem was adopted at that same conference - that of the Red Cross on the white field, and it has been more than a century now that the Red Cross and the Red Crescent have been at the service of humankind, warranting the protection of the victims of armed conflicts and those who help them. The Red Cross symbolizes rescue, hope and protection while being instrumental in the accomplishment of the missions of the International Committee of the Red Cross - the humanitarian aid to the victims of armed conflicts and other acts of violence. Today, this also applies to the attempts to prevent and contain the spreading of the novel coronavirus infection.

The secondary meaning behind the symbol of the Red Cross when it comes to the Russian society is also related to the field of medicine, specifically, in Russia, the painting of ambulance vehicles has always been carried out in accordance with the state standards. Such standards existed in the USSR; there are similar ones in contemporary Russia. GOST R 50574-2002 - Russian Federal Standard "Automobiles, buses and motorcycles of operations units" prescribes distinctive color palettes for ambulances: the major color being white or lemon-yellow (including the vehicles of mobile resuscitation unit), red stripes and a red cross. Consequently, if the red cross is missing from the ambulance livery, this is a direct violation of the Federal Standard.

There is a certain document, which Russian citizens are bound to comply with, although it contradicts the principles of the Geneva Convention. The document in question is Road Traffic Regulations. Certain road signs (i.e., first aid centers, emergency rooms, hospitals) contain the symbol of the red cross, and what it signifies is not the objects of the International Committee of the Red Cross, but regular medical institutions. Moreover, the segment of the specified regulations entitled "The Main Provisions of Transport Approval or Operating Permits" describes an optional sign "Medic", which can be located and fixed either in the fore or in the back of the vehicle driven by paramedics. In this respect, the red cross serves as a medical symbol per se.

The Red Cross as a sign forms a connotational opposition with the sign of the religious cross, and this is revealed through artistic reflection, through material objects. For example, in Moscow there has been unveiled a monument to the medical personnel fighting against COVID-19. These are doctors, nurses, ambulance drivers and, it goes without saying, scientists, researchers that have been studying the novel virus right from the onslaught of the pandemic, and who heroically came up with several viable vaccines. The monumental composition is crowned with the cross, which symbolizes the medical heroic effort, not the religious overtones: the figures of the medics who look as if they have just left the Red Zone of the COVID ICU, and those of scientists who have developed the vaccine. In the background is the globe, our planet. The monument was created by the Honorary People's artist of Russia 
Salavat Shcherbakov, and it was erected on the Alley of Life in the park adjoining Sechenov First Moscow State Medical University, near the buildings where, once, doctors tried to conquer the plague, smallpox, anthrax - and where they prevailed over these diseases.

There is another illustration of the concept analyzed: in 2020, in St. George's Hospital, Saint Petersburg, there was an outbreak of a fire, right in the red zone. Today, the walls of the UCU are covered with portraits of the doctors, and these paintings were performed by the patients themselves. To continue in this vein: there is a memorial on the territory of the Dagestan State Medical University in Makhachkala dedicated to the medical workers who perished when fighting the coronavirus. It features a doctor wearing a protective suit, he or she is kneeling on the floor, with the head bent down.

One could also remember the monument to a morose angel in Saint Petersburg, which is also dedicated to doctors and other medical workers. The author of the memorial, the sculptor Roman Shustov, died from COVID-19 in 2020. Mass media published related news: "The bitter paradox is that people started a smear campaign against the monument and the author and his family, accusing them of corruption and lack of respect for the medical workers, while in 2021, his wife committed suicide."16

The said sculptures are figurative, representational, featuring many minute details. It could be argued that this might be culturally determined, connected with the modus of perception of art typical of Russia and Russians. The realistic art prevails, representational elements abound since they are more accessible to common people.

Apart from the visible color constituting the symbol of the Red Cross, one must allude to the mental, ideational color, which is encoded in a concept or a notion verbally. In the latter case, the signifiers are verbal nominations or descriptions of the visible color, which may transfigure into the semantic plane and which may be merely more or less implied [11]. The color code turns into an expression of the tertiary meaning of the symbol of the red cross, which sort of complements the verbal expression and which is dependent on its use, and since its signifiers manifest exclusively qua the signified of the verbal expressions, their visual character might be reduced. The red color is inextricably linked with such a phenomenon as "the red zone" - the COVID ICU, where the medical personnel can only stay and work if they wear protective gear.

Of no less importance is the fact that during the pandemic the red color has become a significant part of the cultural milieu, having become predominant in the color palette of the newsrooms of the state-sponsored TV channels, even influencing the dress code of the TV anchors. Conversely, it is argued that prior to the COVID era the use of the specified color was not deemed appropriate for the TV presenters, since it was believed to promote the feelings of anxiety and bolster aggression, which could lead to the negative perception of the broadcast news. However, these days, the color red stands for positivity, underlining the joint efforts of the healthcare system and the state in our common fight against the deadly virus. Red intensifies the connotative meaning of the cross - uttering the idea of rescue, salvation, fighting against the com-

\footnotetext{
16 "A phonendoscope instead of a machine gun." https://newizv.ru/news/city/19-09-2021/vmesto-avtomata-fonendoskop-moskvichi-ne-v-vostorge-ot-pamyatnika-geroyam-medikam. Accessed on 20th September 2021. (In Russian).
} 
mon enemy, and the consolidation of society. The packaging of the Russian COVID vaccine employs the colors of Russia's state flag, wherein alongside white and blue red is featured, and that may speak to the politicalization of the manufactured vaccines, the topic that is being explored in the studies of Ali Haif Abbas $[1,2]$.

Therefore, it may be posited that the meaning of the symbol of the cross qua the foremost symbol that expresses the unity and unison of various manifestations of a person in the world is being gradually lost. At present, a religious cross is acquiring a negative connotation, whilst the medical cross has become a sign of salvation, incorporating the positive symbolic meaning of the Russian Orthodox Cross. This profound and momentous interpretation becomes accessible and may be revealed if the tradition of symbol interpretation perseveres, and that involves the ability to artistically transform them (Fig. 3).

\section{Conclusions}

The issue of stereotyping of the Russian Orthodox Church in the fake news in the context of the global pandemic and vaccination has been analyzed in terms of interdisciplinary approach.

It has been established that fake news, unlike authentic, is similar to a virus, as it were, it spreads faster, infiltrates deeper, and later on, it transforms into other, newlyminted fakes.

The coronavirus infection caused by the SARS-CoV-2 coronavirus has accelerated the formation of a huge number of rumors and speculations about the Russian Orthodox Church.

Misinformation and fake news evoke strong negative feelings and emotions, thus boosting the circulation of the former.

Any significant public address of the Russian Orthodox Church in this respect is inevitably accompanied by scandalizing. Allegedly, in Russia, the Russian Orthodox Church is a social institution that has suffered the most from the current pandemic. The majority of the residents of the largest Orthodox monasteries - be it the pilgrims

Fig. 3 Those in Need of a Miracle, painted by Yulia Erokhina

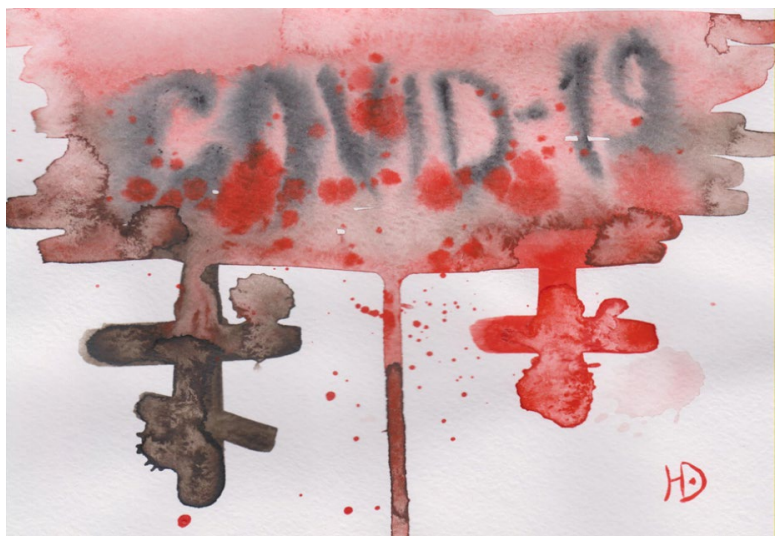


or Father Superior - have been infected and fallen ill, and this comes as no surprise, for crowds are harder to control in churches and monasteries than, say, in governmental facilities, not to mention that the format of the religious communication (during the confession, among others) calls for a rather close, intimate contact. One cannot officially prohibit the attendance of churches and public worship on account of no viable vaccination certificate. At that, the church officials themselves tend to explain what is happening mystically, as it were, in terms of God's wrath and apostacy.

When falsifying information and spreading fake news, a subject responsible seeks to promote fear, chaos and ambiguity, thus deliberately increasing social entropy. Social entropy is an objective indispensable condition of societal evolution, the society seen qua complex self-organizing unbalanced (non-equilibrium) open system. Social dynamic is largely determined by the adequate legal regulation and its impact on social entropy. To analyze fake news as social entropy factors, affecting its increase or decrease, as well as the attainment of the entropy optimum, it was necessary to define the common term "entropy factor" - that is, real conditions in which social entropy emerges, exists, and transforms; also, the factors affecting social entropy have been identified. In the conditions of the global pandemic, fake news serves as exterior factors impacting societal entropy optimum.

In that regard, fake news featuring the Russian Orthodox Church can be divided into several categories: fake news about the institution itself, the pandemic and the vaccination campaign may be viewed as exterior social entropy factors while the destructive actions of certain members of the clergy may be designated qua interior factors. Fake news, being social information, may reduce the level of incompetence thus increasing "knowledge", in a manner of speaking. The notions of knowledge and ignorance are related to the concepts of a system vs. chaos. Entropy, which helps define and qualify information, reducing uncertainty and ambiguity, characterizes irregularity, disorder, and chaos.

In contrast to entropy, there has been developed a notion of negentropy, which characterizes systems and systemic order. A meaningful message, a counterargument or repudiation of fake news - all these are examples of negentropy. Information cancelling irregularity, including fake news, serves as an example of entropy. Fake news is programmed to stimulate a psychological response, which will be purely automatic, a reflex of sorts. Fake news appears to serve as triggers for the generation of negative stereotypes about the Russian Orthodox Church. The formation of a stereotype passes three stages: leveling, sharpening, and assimilation. In this connection, the accuracy of information loses its relevance; what matters is its emotiveness.

It is possible to employ legal regulation of social relations as a means of reduction of the rate of social entropy and attainment of entropy optimum. For proper legal regulation of social entropy law ought to take into account social needs and interests of people, the level of freedom essential for a person's self-fulfillment, personal values and those of the society at large, spirituality, culture, worldview and behavior of a person, social psychology, rational and irrational aspects of human behavior in the conditions of the COVID-19 pandemic. The normative legal acts adopted under such circumstances are mostly of a prohibitory, restrictive nature. The attainment of entropy optimum via legal regulation largely depends on the factors analyzed prior, which underlie both increase or decrease of social entropy. 
The pandemic discourse is characterized by certain connotative attributes, such as negative connotation and emotiveness, globalization of perception, uncontrollability and unpredictability. The semiotic method (through an iconic sign) allows for the explication of the connotative meaning of the nonverbal symbol of the cross, which tends to be the carrier of social symbolism in Russia. The symbol of the Russian Orthodox Cross has a complex secondary connotative meaning.

The positive symbolic meaning behind the Russian Orthodox Cross finds its manifestation in the concepts of salvation, hope, and protection. The cross retains a negative connotative meaning, for the most part, if it occurs outside the sphere of religion.

In the conditions of the pandemic, one may witness a tendency to equate a symbol of the cross with a sign. Simultaneously, the medical cross functions as a symbol of salvation, thus incorporating the positive symbolic meaning of the Russian Orthodox Cross.

Acknowledgements the given research has been developed within the framework of the project "Law and Art", which is being carried out at Faculty of Law, HSE University, Moscow, Russian Federation.

\section{References}

1. Abbas, Ali Haif. 2020. Politicizing the Pandemic: A Schemata Analysis of COVID-19 News in Two Selected Newspapers. International Journal for the Semiotics of Law. https://doi.org/10.1007/ s11196-020-09745-2.

2. Abbas, Ali Haif. 2021. Politicizing COVID-19 Vaccines in the Press: A Critical Discourse Analysis. International Journal for the Semiotics of Law. https://doi.org/10.1007/s11196-021-09857-3.

3. Akhiezer, Alexandr. 1998. Rossia: kritika istoricheskogo opyta (Sotsiokulturnaya dinamika Rossii) [Russia: A Critique of Historical Experience (Socio-cultural Dynamics of Russian Society]. Novosibirsk: Sibirskiy Khronograf.

4. Barsukov, Ivan. 1883. Innokentiy, mitropolit Moskovskiy i Kolomenskiy, po ego sochineniyam, pis'mam i rasskazam sovremennikov [St. Innocent of Moscow and Kolomna, according to his Written Works, Letters, and Memoirs of the Contemporaries]. Moskva: Sinodalnaya Tipografiya.

5. Brinev, Konstantin. 2009. Lingvisticheskaya ekspertiza: Spravochnye materialy [Linguistic Expertise: Background Material]. Barnaul: AltGTU.

6. Bryant, F. B., and P. R. Yarnold. 1995. Principal Components Analysis and Exploratory and Confirmatory Factor Analysis. In book Grimm, L. G. and Yarnold P. R. (eds.). Reading and Understanding Multivariate Analysis. Washington, DC: American Psychological Association.

7. Cassirer, E. 1953. The Philosophy of Symbolic Forms. New Haven: Yale University Press.

8. Cassirer, E. 1955. The Philosophy of Symbolic Forms. New Haven: Yale University Press.

9. Cassirer, E. 1957. The Philosophy of Symbolic Forms. New Haven: Yale University Press.

10. Cassirer, E. 1985. Symbol, Technik, Sprache. Aufsätze aus den Jahren 1927-1933. Hamburg: Meiner.

11. Chertov, Leonid. 2014. Znakovaya prizma: stat'i po obshchej i prostranstvennoj semiotike [Sign Prism: Articles on General and Spatial Semiotics]. Moskva: Yazyki slavyanskoj kul'tury.

12. Collins, B., D. T. Hoang, N. T. Nguyen, and D. Hwang. 2020. Trends in combating fake news on social media - a survey. Journal of Information and Telecommunication 5 (1): 1-20.doi.org/ $10.1080 / 24751839.2020 .1847379$.

13. Erokhina, Yulia. 2008. Entropiynye protsessy v russkoy revolyutsii 1905-1907 gg. [Entropy Processes in 1905-1907 Russian Revolution]. In Kontsept 'Revolyutsiya'v sovremennom politicheskom diskurse, ed. by L. E. Blyakher, B. V. Mezhuev, A. V. Pavlov. Sankt-Peterburg: Aleteya.

14. Erokhina, Yulia. 2016. Novye smysly ponyatiya 'pravovaya entropiya' [New Meanings of 'Legal Entropy']. Rossiyskiy zhurnal pravovykh issledovaniy 1 (6): 99-108. 
15. Erokhina, Yulia. 2021. Semiotic Interpretation of the Sign "Ecclesiastical Court" within the Framework of Legal Precepts in Terms of Temporality and Spatiality (Case of Russia). International Journal for the Semiotics of Law 34: 783-802.

16. Factory razvitiya chelovecheskoy sub'ektivnosti [The Factors of Human Subjectivity Development]. 1989. Ed. by S. S. Batenin. Leningrad: LGPI.

17. Florenskiy, Pavel. 1994. Sochineniya v chetyrekh tomakh [Works in Four Volumes]. Moskva: Mysl'.

18. Floridi, Luciano, ed. 2008. The Blackwell Guide to the Philosophy of Computing and Information. Blackwell: John Wiley \& Sons.

19. Frolov, Alexey. 2019. Factory vliyayushchie na transformatsiyu pravosoznaniya v sovremennoy Rossii [Factors Influencing Legal Awareness Transformation in Modern Russia]. Vestnik Voronezhskogo gosudarstvennogo universiteta. Seriya: Pravo 2(37): 26-37.

20. Gordon, Pennycook, and G. David, and Rand. 2021. The Psychology of Fake News. Trends in Cognitive Sciences 25(5): 388-402. https://doi.org/10.1016/j.tics.2021.02.007.

21. Gorsuch, R. L. 1983. Factor Analysis. Hillsdale, NJ: Lawrence Erlbaum Associates.

22. Gradon, Kacper. 2020. Crime in the Time of the Plague: Fake News Pandemic and the Challenges to Law-enforcement and Intelligence Community. Society Register 4(2): 133-148. https://doi. org/10.14746/sr.2020.4.2.10.

23. Gubin, Valerij. 1997. Istoriya s entropiey [The Story of Entropy]. Filosofskie Nauki 3-4: 98-120.

24. Gurkina, Elena. 10 stereotipov o pravoslavnykh [Ten Stereotypes on Orthodox Believers]. (In Russian). https://vera21.ru/10-stereotipov-o-pravoslavii. Accessed on 20th September 2021.

25. Haken, Hermann. 2003. Tayny prirody. Sinergetika: Nauka o vzaimodeistvii [The Secrets of Nature. Synergetics: Theory of Interaction]. Moskva: Institut Kompyuternykh Issledovaniy.

26. Harman, Harry H. 1976. Modern Factor Analysis. Chicago: University of Chicago Press.

27. Hovorun, Archimandrite Cyril. 2021. 'Bogoslovie kovida' ili 'Znamenatel'naya burya' koronovirusnoi pandemii. ['COVID Theology', or the 'Significant Storm' of the Coronavirus Pandemic]. Gosudarstvo, religiya, tserkov' $v$ Rossii $i$ za rubezhom 39(1): 58-75] https://doi. org/10.22394/2073-7203-2021-39-1-58-75.

28. Ivanov, Andrey. 1999. Razvitie i entropiya. [Development and Entropy]. In Problema razvitiya $v$ gumanitarnom i sotsialno-economicheskom znanii. Sankt- Peterburg: SPbGETU "LETI".

29. Ilyushkin, Vitaliy. 2014. Stereotipizatsiya kak vazhniy faktor v vospriyatii i poznanii lyudmi drug druga [Stereotypization as a Significant Factor in the Perception and Cognition of People by Each Other]. European Science 1: 31-36.

30. Isaev, Alexey. 2010. Rol' i mesto Russkoy Pravoslavnoy tserkvi v razvitii gosudarstva: istoriya i sovremennost [The Role and Place of the Russian Orthodox Church in the State Development: History and Present Time]. Srednerusskiy vestnik obshchestvennykh nauk 1: 138-148.

31. Kajtez, Nikola. 2019. Filosofiya entropii. Negentropiynaya perspektiva [The Philosophy of Entropy. Negentropy Perspective]. Sankt-Peterburg: Aleteya.

32. Khachaturian, A. M. 1990. Sotsialnye factory razvitiya zakonodatelstva soyuznoy respubliki [Social Factors of a Federal Republic Legislation Development]. Erevan: Ayastan.

33. Kiriy, Valentina, and Oleg Gutsa. 2016. Issledovanie spetsifiki primeneniya faktora vremeni v sovremennykh ekonomicheskikh protsessakh [Research on Some Aspects of Time Factor Application in Modern Economic Processes]. Traektoriâ Nauki [Path of Science] 2(5): 1.36-1.43.

34. Kolmogorov, Andrey. 1965. Problemy teorii veroyatnostei i matematicheskoi statistiki [The Problems in the Probability Theory and Mathematical Statistics]. Vestnik Academii Nauk SSSR 5: 442-445.

35. Kuznetsov, A. N., E. A. Novruzlu, and S. V. Starostenko. 2014. Rol' faktornogo analiza v issledovanii effektivnosti raboty predpriyatiya [The Role of Factor Analysis in the Study of the Efficiency of the Enterprise]. Strategii Biznesa 3 (5): 10-12.

36. Kunitcina, Valentina. 1971. Sotsialnye stereotipy - uslovie i produkt sotsializatsii [Social Stereotypes: as a Condition for and Product of Socialization]. Uchenye Zapiski LGU, NIIKSI 9: 184-193.

37. Lakoff, George. 2018. A Modest Proposal: \#ProtectTheTruth. http://georgelakoff.com/2018/01/13/amodest-proposal-protectthetruth. Accessed on 12th September 2021.

38. Losev, Alexey. 1982. Znak. Simvol. Myf. [Sign. Symbol. Myth]. Moskva: Izdatel'stvo Moskovskogo universiteta.

39. Losev, Alexey. 1995. Problema simvola i realisticheskoe iskusstvo [The Problem of Symbol and Realistic Art]. Moskva: Iskusstvo.

40. Lotman, Juri. 1987. Simvol v sisteme kultury [The Symbol in the System of Culture]. Tartu: TGU. 
41. Mamardashvili, Merab, and Alexandr Piatigorsky. 1997. Simvol i soznanie. Metafizicheskie razmyshleniya o soznanii, simvolike i yazyke [Symbol and Consciousness. Metaphysical Reasoning about Consciousness, Symbolism and Language]. Moskva: Shkola: "Yazyki russkoy kultury.".

42. Mamardashvili, Merab. 2010. The Problem of Consciousness and the Philosopher's Calling. Russian Studies in Philosophy 49.2: 8-27.

43. Markin, Sergey, and Alexey Chizhov. 2003. Otsenka vliyaniya faktorov vneshney sredy na zdorovie lyudey [Estimation of Influence Factors External Environment on Health of the Population]. Vestnik Rossiyskogo universiteta druzhby narodov. Seriya: Ekologiya i bezopasnost'zhiznedeyatel'nosti 9: 162-170.

44. Mirosedi, Svetlana, Mirosedi Tatiana, and Yulia Veremeeva. 2016. Faktory i rezervy uvelicheniya pribyli predpriyatiya [Factors and Reserves Determining the Profit of the Enterprise]. Simvol nauki 4-1: 143-146.

45. Narinyani, Alexandr. 2006. Ne-faktory: kratkoe vvedenie. [Non-factors: Short Introduction]. Novosti iskusstvennogo intellekta 2: 52-63.

46. O’Hara, Robert. 1961. Media for Million. New York: Random House.

47. Olszowski, Rafal. 2021. Combating Fake News with the Use of Collective Intelligence in Hybrid Systems. Conference: 37th International Business Information Management Association (IBIMA). https://doi.org/10.6084/m9.figshare.14045708.v5.

48. Pavlova (Erokhina), Yulia. 2005. Pravovaya Entropiya [Legal Entropy]. Vladimir: Vladimirskiy yuridicheskiy institut Federalnoy sluzhby ispolneniya nakazaniya.

49. Penelhum, T. 2010. Fideism. In book Taliaferro, Ch., Draper, P. and Quinn Ph.L. (eds). A Companion to Philosophy of Religion: 441-448. Malden, MA: Wiley-Blackwell.

50. Pett, Marjorie, and Nancy M. Lackey, and John J. Sullivan. 2003. Making Sense of Factor Analysis: the Use of Factor Analysis for Instrument Development in Health Care Research. Thousand Oaks, CA: Sage Publications.

51. Phillips Andrew. O semi vidakh poddelnogo Pravoslaviya [On Seven Types of False Orthodoxy]. https://pravoslavie.ru/131550.131550/html. Accessed on 20th September 2021.

52. Pochepcov, Georgiy. 2019. (Dez)informatsiya [(Dis)information]. Kiev: PALIVODA A.B.

53. Polenina, Svetlana, Oleg Gavrilov, Nina Koldaeva, Evgeniy Kumanin, and Vladimir Levanskiy. 1981. Issledovanie sotsialnykh faktorov zakonodatelnoy deyatelnosti soyuznykh respublik [Research on Social Factors of Federal Republic Legislative Work]. Pravovedenie 3: 51-58.

54. Prigogine, Ilya, and Izabelle Stengers. 2001. Poryadok iz khaosa. Novy dialog cheloveka s prirodoy. [Oder out of Chaos. Man's New Dialogue with Nature]. Moskva: Editorial URSS.

55. Reichenbach, Hans. 1962. Napravlenie vremeny [The Direction of Time]. Moskva: Inostrannaya literatura.

56. Sedov, Evgeniy. 1965. K voprosu o sootnoshenii entropii informatsionnykh protsessov i fizicheskoy entropii [On the Relationship between Information Entropy and Physical Entropy]. Voprosy filosofii 1: $135-145$.

57. Sedov, Evgeniy. 1976. Evolutsiya i Informatsiya [Evolution and Information]. Moskva: Nauka.

58. Sedov, Evgeniy. 1985. Vzaimosvyaz' energii, informatsii i entropii v protsessakh upravleniya $i$ samoorganizatsii. Informatsiya i upravlenie [The relationship of Energy, Information and Entropy in the Processes of Management and Self-organization. Information and Management]. Moskva: Nauka.

59. Shabani, Shaban, and Maria Sokhn. 2018. Hybrid Machine-Crowd Approach for Fake News Detection. 2018. IEEE 4th International Conference on Collaboration and Internet Computing (CIC): 299-306.

60. Shannon, Claude. 1948. A Mathematical Theory of Communication. Bell System Technical Journal 27: $379-423,623-656$.

61. Shannon, Claude. 1963. Raboty po teorii informatsii i kibernetike [Works on the Theory of Information and Cybernetics]. Moskva: Inostrannaya literatura.

62. Shevtsov, Konstantin. 2019. Sovremenny mir kak obshchestvo feika [Modern World as a Fake Society]. Vestnik Russkoy khristianskoy gumanitarnoy akademii 20 (3): 52-62.

63. Temirgazina, Zifa, and Malgorzata Luczyk. 2020. Semiotika "pandemicheskogo" diskursa: "novoyaz" epokhi karantina [Semiotics of "Pandemic" Discourse: "Newspeak" of Quarantine Era]. Filologicheskie nauki 6: 30-38. 
64. The Science of Fake News: Addressing Fake News Requires a Multidisciplinary Effort. 2018. / Lazer, David M.J., Matthew A. Baum, Yochai Benkler, Adam J. Berinsky, Kelly M. Greenhill, Filippo Menczer, Miriam J. Metzger, Brendan Nyhan, Gordon Pennycook, David Rothschild, Michael Schudson, Steven A. Sloman, Cass R. Sunstein, Emily A. Thorson, Duncan J. Watts, and Jonathan L. Zittrain In: Science, Vol. 359, No. 6380, 09.03.2018, p. 1094-1096. https://doi.org/10.1126/science.aao2998.

65. Trubetskoy, Evgeniy. 1999. Entsiklopediya prava [The Encyclopedia of Law]. Sankt-Peterburg: Yuridicheskiy institut.

66. Tsvetkov, V.Ya. 2014. Dichotomous Systemic Analysis. Life Science Journal 11 (6): 586-590.

67. Tyurenkov, Mikhail. "Ne prinuzhdai, ne osuzhdai, ne raskalyvai”: strasti po vaktsinatsii zatronuli Russkuyu Tserkov' ["Do not force, do not condemn, do not split": The passion for vaccination has affected the Russian Church]. https://pravoslavie.ru/140652.html. Accessed on 18th September 2021.

68. Ullah, Haroon. The Digital War against Isis is Being Lost. What Should be Done? www.theguardian. com/commentisfree/2017/nov/13/digital-war-against-isis-lost-islamic-state-mohamad-al-arefe. Accessed on 12th September 2021.

69. Velicer, W. F., C. A. Eaton, and J. L. Fava. 2000. Construct Explication Through Factor or Component Analysis: a Review and Evaluation of Alternative Procedures for Determining the Number of Factors or Components. In book Goffin, R. D. and Helmes, E. (eds.). Problems and Solutions in Human Assessment: Honoring Douglas Jackson at seventy. Boston, MA: Kluwer.

70. Wiener, Norbert. 1948. Cybernetics or Control and Communication in the Animal and the Machine. Paris: The Technology Press and John Wiley \& Soris Inc. New York - Herman et Cie.

71. Wiener, Norbert. 1958. Kibernetika, ili upravlenie i svyaz'v zhivotnom i mashine [Cybernetics or Control and Communication in the Animal and the Machine]. Moskva: Sovetskoe radio.

72. Wiener, Norbert. 1958. Kibernetica i obshchestvo [Cybernetics and Society]. Moskva: Inostrannaya literatura.

73. Yelsukov, Pavel. 2017. Informatsiya umenshayushchaya neopredelennost' i informatsiya uvelichivayushchaya soderzhatelnost' [Information, Reducing Uncertainty and Information Increasing content]. Obrazovatelnye resursy i tekhnologii 3 (20): 62-68.

74. Zhou, Xinyi, and Reza Zafrani. 2020. A Survey of Fake News: Fundamental Theories, Detection Methods, and Opportunities. ACM Computing Surveys 53 (5): 1-40. https://doi.org/10.1145/3395046.

75. Zhulanov, Alexander. 1968. Entropiya i kolichestvo informatsii [Entropy and the Quantity of Information]. Uchenye Zapiski Permskogo Gosudarstvennogo Pedagogicheskogo Instituta 51: 49-64.

76. Zhulanov, Alexander. 1972. Negentropiyniy printsip informatsii i ego filosofskoe soderzhanie [The Negentropy Principle of Information and its Philosophical Meaning]. Uchenye Zapiski Permskogo Gosudarstvennogo Pedagogicheskogo Instituta 104: 29-40.

Publisher's Note Springer Nature remains neutral with regard to jurisdictional claims in published maps and institutional affiliations. 